\title{
IMPLEMENTASI BUDAYA AKADEMIK \\ BAGI KETERAMPILAN SOSIAL SISWA SEKOLAH DASAR
}

\author{
Meidawati Suswandari \\ PGSD, FKIP, Universitas Veteran Bangun Nusantara, Sukoharjo, Indonesia \\ moetis_meida@yahoo.co.id
}

\begin{abstract}
In fact, humans are also social beings who have dependence on living with other humans, especially in creating social skills for themselves. This study aims to describe the implementation of academic culture for elementary school students' social skills. This type of research uses a descriptive-qualitative approach. The sampling technique used purposive sampling. The informants in this study were 1 grade $V$ teacher and 31 grade $V$ students at SD $N$ Bekonang 1 , Sukoharjo. The data techniques used include observation and documentation. Data analysis using data reduction techniques, data presentation, and withdrawal. The results of the disinformation study show that the implementation of academic culture for students' social skills at SD N Bekonang 1, Sukoharjo is through student learning in class. Learning will have an impact on the order of students socially to be skilled in dealing with and sensitive in their surroundings. Forms of academic culture through aspects of cooperation between students in groups, other students, expressing and listening to opinions, caring for friends, helping each other, and academic competition. Learning that takes place, students' social skills make students more skilled in positioning themselves and the existence of other people and people around students.
\end{abstract}

Keywords: academic culture, elementary school, social skills

\begin{abstract}
Abstrak
Pada dasarnya manusia juga sebagai makhluk sosial yang memiliki ketergantungan hidup bersama manusia lain, apalagi dalam menciptakan keterampilan sosial bagi dirinya Penelitian ini bertujuan untuk mendeskripsikan implementasi budaya akademik bagi keterampilan sosial siswa Sekolah Dasar. Jenis penelitian menggunakan pendekatan deskriptif-kualitatif. Teknik pengambilan sampel menggunakan purposive sampling. Informan dalam penelitian ini adalah 1 orang guru kelas $V$ dan 31 siswa kelas V SD N Bekonang 1, Sukoharjo. Teknik pengumpulan data yang digunakan meliputi observasi dan dokumentasi. Analisis data menggunakan teknik reduksi data, penyajian data, dan penarikan kesimpulan. Hasil penelitian disimpulkan bahwa implementasi budaya akademik bagi keterampilan sosial siswa di SD N Bekonang 1, Sukoharjo adalah melalui pembelajaran siswa di kelas. Pembelajaran akan berdampak pada pembentukan kebiasaan siswa secara sosial untuk terampil dalam menghadapi dan peka di lingkungan sekitarnya. Bentuk budaya akademik melalui aspek kerjasama antar siswa dalam berkelompok, menolong siswa lain, menyampaikan dan mendengarkan pendapat, peduli teman, saling membantu, serta persaingan akademis. Pembelajaran yang berlangsung tersebut, keterampilan sosial siswa menjadikan siswa lebih terampil dalam memposisikan diri dan keberadaan orang lain dan orang sekitar siswa.
\end{abstract}

Kata Kunci: budaya akademik, sekolah dasar, keterampilan sosial

Program Studi Pendidikan Guru Madrasah Ibtidaiyah

STAI Al-Azhar Menganti Gresik, Indonesia

\section{Pendahuluan}

Keterampilan sosial merupakan keterampilan yang timbul akibat hubungan antar manusia dengan manusia lain yang saling membutuhkan. Saling membutuhkan antar manusia tidak lepas dari kemampuan dalam mengembangkan keterampilan sosialnya. Manusia dituntut untuk memiliki keterampilan sosial yang semakin baik maka akan semakin baik pula hubungan sosial dengan lingkungan sekitarnya. Lingkungan tersebut yang membentuk manusia untuk selalu saling berhubungan timbal balik dengan manusia lain. Karena pada 
ZAHRA: Research And Tought Elmentary School Of Islam Journal Vol. (2) (1), (Maret)(2021), (Halaman)(1-12)| 2 dasarnya manusia juga sebagai makhluk sosial yang memiliki ketergantungan hidup bersama manusia lain, apalagi dalam menciptakan keterampilan sosial bagi dirinya (Janah, 2018: 66).

Observasi awal sebelum pandemi Corona dilakukan penelitian di Sekolah Dasar Negeri Bekonang 1, Sukoharjo diperoleh data siswa dalam penguasaan keterampilan sosial di kelas dalam kategori Kurang Baik/Maksimal. Hal ini terlihat dari instrument observasi awal pada aspek kerjasama antar siswa dalam berkelompok (20\%), menolong siswa lain (25\%), serta menyampaikan dan mendengarkan pendapat (20\%). Beberapa sikap lain yang menunjukkan rendahnya keterampilan sosial antara lain: masih terdapat siswa yang tidak mengetahui/kurang peduli bahwa ada siswa yang tidak masuk sekolah (35\%) serta tidak membantu/meminjamkan penggaris dan penghapus kepada teman lain (25\%) serta kurang maksimalnya persaingan akademis pada saat pembelajaran (20\%). Observasi rendahnya keterampilan sosial ini tersaji dalam grafik berikut.

Gambar 1. Keterampilan Sosial di SD N Bekonang 1, Sukoharjo

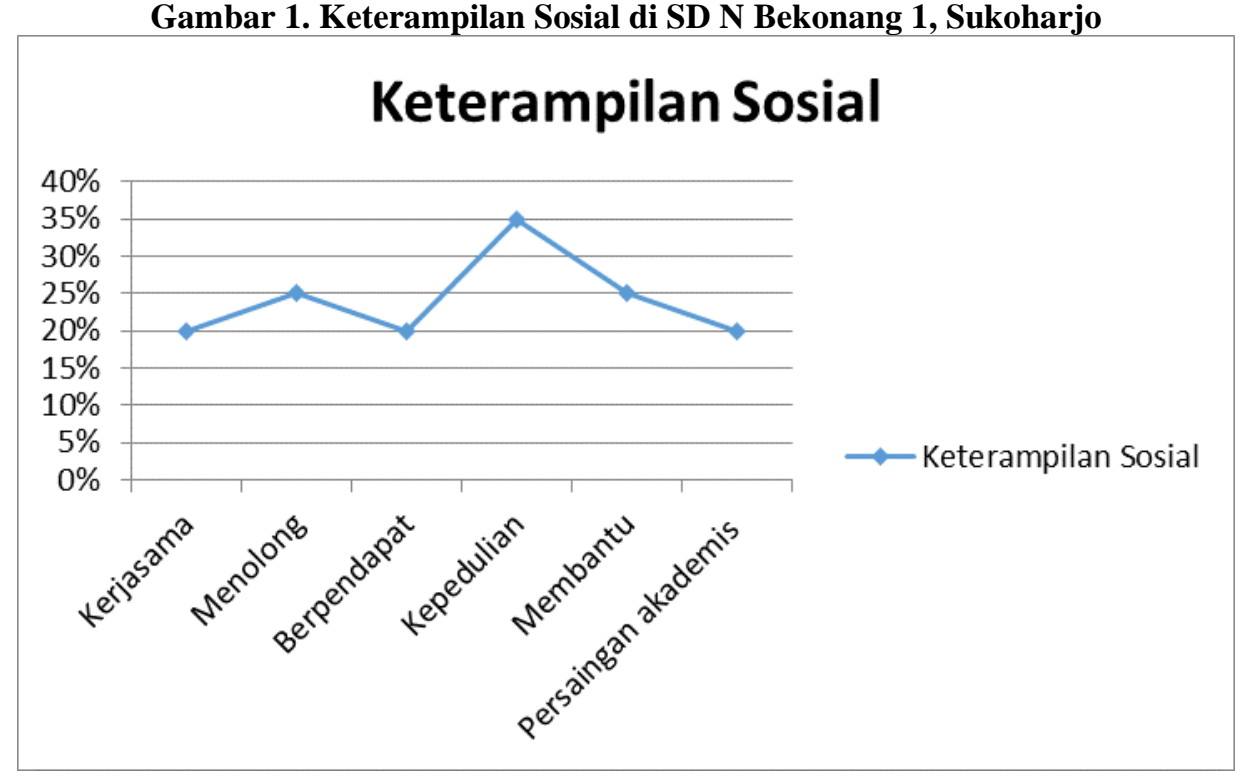

Tinggi rendahnya keterampilan sosial tersebut merupakan pengintegrasian yang diadopsi dari Marzius bahwa kriteria interpretasi keterampilan sosial tergolong dalam tiga skor persentase, yaitu (1) 0\%-40\% kurang baik, (2) 41\%-70\% cukup baik, dan (3) 71\%-100\% kriteria baik (Marzius \& Pargito, 2005: 2).

Kecenderungan siswa yang rendah dalam keterampilan sosial yaitu sulit untuk mengontrol diri dengan baik dan sulit untuk berempati serta sulit berinteraksi dengan orang lain. Sementara itu, kemampuan anak berinteraksi dengan orang lain sangat bergantung pada pola asuh orang tuanya. Ketika seorang anak diberikan kesempatan dan didorong untuk bersosialisasi dengan lingkungannya maka keterampilan sosial anak akan terbentuk dengan sendirinya. Namun sebaliknya, ketika seorang anak tanpa adanya kesempatan untuk 
ZAHRA: Research And Tought Elmentary School Of Islam Journal Vol. (2) (1), (Maret)(2021), (Halaman)(1-12)| 3 bersosialisasi dengan lingkungannya ada kecenderungan anak akan menjadi takut, malu, dan serta sulit untuk berinteraksi dengan lingkungannya (Horstman, 2018: 26-27).

Adanya interaksi sosial dengan lingkungan sekitar maka ketrampilan sosial seseorang dapat ditingkatkan dalam kehidupan anak/siswa. Keterampilan sosial yang dapat berkembang dengan baik kemudian menghasilkan pengalaman dari berbagai kegiatan dan situasi kondisi yang dialami. Hal ini terwujud dalam bentuk siswa berpartisipasi aktif dalam mengikuti pembelajaran dalam menyesuaikan diri dengan lingkungannya dan kepercayaan diri atas kemampuan dan keterampilan yang dimiliki sehingga siswa tidak diam dan merasa percaya diri (Hammond, Flook, Harvey, Barron, \& Osher, 2019: 36).

Munculnya keterampilan sosial dalam bentuk kerjasama di kelas mengharuskan siswa untuk bersosialisasi secara efektif. Siswa dengan kemampuan dan keterampilan sosial yang terbatas maka akan kesulitan dalam menjalin hubungan sosial. Siswa yang mempunyai keterampilan sosial yang tinggi dapat menumbuhkan minat yang lebih besar di sekolah sehingga bisa berdampak baik bagi akademis anak. Namun keterampilan sosial anak yang kurang baik dapat menyebabkan anak kurang mampu menjalin hubungan yang baik dengan lingkungan di sekolahnya. Oleh sebab itu, diperlukan suasana pembelajaran yang kondusif dalam bentuk system dan proses pembelajaran yang menyenangkan dan interaktif. Hal ini dirumuskan dalam konteks penciptaan budaya akademik di kelas/sekolah.

Budaya akademik adalah budaya akademik adalah "cara hidup masyarakat ilmiah yang majemuk, multikultural yang bernaung dalam sebuah institusi yang mendasarkan diri pada nilai-nilai kebenaran ilmiah dan objektivitas". Artinya bahwa nilai kebenaran yang telah disepakati bersama dan secara obyektif dalam masyarakat menjadi tuntunan untuk hidup berdampingan sehingga membudaya secara turun temurun untuk menciptakan suasana masyarakat ilmiah yang saling berdampingan. Budaya akademik muncul dari sebuah proses panjang yang meliputi berbagai kegiatan akademik yang terencana secara sistematis. Budaya akademik tumbuh dan berkembang melalui interaksi antara sivitas akademika secara terus menerus. Interaksi yang dimunculkan dalam bentuk perilaku, tradisi, dan budaya ilmiah di dalam masyarakatnya. Suasana budaya akademik tidak bisa terlaksana dan terwujud dengan sendirinya, akan tetapi harus melalui perencanaan, pengorganisasi, pengoperasian dan memanajemenkan dengan baik. Budaya akademik adalah seperangkat nilai, aturan, pengetahuan, pengalaman, sikap, waktu, dan peran yang diperoleh dalam proses interaksi edukasi pada tataran pendidikan tinggi. Dengan kata lain, budaya akademik adalah cara hidup dalam masyarakat ilmiah dengan multikulturalnya dan kemajemukannya yang 
ZAHRA: Research And Tought Elmentary School Of Islam Journal Vol. (2) (1), (Maret)(2021), (Halaman)(1-12)| 4 mendasarkan diri pada nilai-nilai kebenaran ilmiah dan objektivitas (Santana, 2009: 125127).

Konsep budaya akademik di atas, berdampak pada proses pembelajaran yang digunakan oleh guru dalam menciptakan pembelajaran yang kondusif, efektif dan menyenangkan. Seperti dalam penelitian yang dilakukan oleh Arif dalam penelitiannya yang bertujuan untuk mengetahui dan menguji data-data empirik terkait hubungan budaya akademik dan munculnya budaya organisasi pada kinerja guru. Penelitiannya menggunakan metode survei dengan pendekatan korelasional dan regresional terhadap data-data kuantitatif yang diperoleh dari guru-guru Sekolah Dasar Islam Al-Azhar BSD. Sampel penelitian diperoleh dari sejumlah 93 responden yang yang merupakan guru Sekolah Islam Al-Azhar BSD pada tahun ajaran 2016-2017. Pengumpulan data dilakukan dengan menggunakan teknik angket/kuesioner, observasi, dan dokumentasi. Jenis analisis yang digunakan adalah analisa korelasi dan regresi yang dijabarkan secara deskriptif. Hasil dari penelitian ada 3, yaitu Pertama, terdapat hubungan yang positif dan signifikan budaya akademik terhadap kinerja guru dengan hasil koefisien determinasi (R2) sebesar 64,6\% dan koefisien korelasi (r) sebesar 0,804. Kedua, terdapat hubungan yang positif dan signifikan budaya organisasi terhadap kinerja guru dengan koefisien determinasi (R2) sebesar 53,7\% dan koefisien korelasi (r) sebesar 0,736. Ketiga, terdapat hubungan yang positif dan signifikan budaya akademik dan budaya organisasi secara simultan terhadap kinerja guru. Koefisien korelasi sebesar 0,813 sedangkan koefisien determinasi sebesar 66,1\%. Dengan demikian dengan adanya kinerja guru yang dipengaruhi oleh budaya akademik dapat meningkatkan mutu pembelajaran di kelas (Arif, 2019).

Budaya akademik yang dapat juga berpengaruh pada kinerja guru dari penelitian Arif di atas, juga diperdalam oleh Patonah dalam penelitian yang berjudul "Pengaruh budaya akademik sekolah terhadap motivasi belajar siswa dan implikasinya terhadap hasil belajar siswa (survey pada siswa Madrasah Ibtidaiyah Swasta di Kota Banjar)”. Berdasarkan analisis statistik menunjukkan bahwa budaya akademik mempengaruhi motivasi belajar siswa sebesar 20,79\%. Budaya akademik dapat mempengaruhi adanya motivasi belajar siswa sebesar 3,03\%. Artifak memengaruhi motivasi belajar siswa sekitar 0,98\%. Sedangkan pengaruh simultan antara budaya sosial, budaya akademik, kualitas budaya, artifak terhadap motivasi belajar siswa sekitar 61,9\%. Budaya sosial mempengaruhi prestasi belajar siswa sekitar 0,03\%. Budaya akademik mempengaruhi prestasi belajar siswa sekitar 1,96\%. Budaya kualitas mempengaruhi prestasi belajar siswa sekitar 2,10\%. Artifak mempengaruhi prestasi belajar siswa sekitar 6,50\%. Motivasi belajar siswa mempengaruhi prestasi belajar siswa 
ZAHRA: Research And Tought Elmentary School Of Islam Journal Vol. (2) (1), (Maret)(2021), (Halaman)(1-12)| 5 sekitar 60,53\%. Sedangkan pengaruh simultan antara budaya sosial, budaya akademik, budaya kualitas, artifak dan motivasi belajar siswa terhadap prestasi belajar siswa sekitar 77,6\% (Patonah, 2016).

Adanya pengaruh yang memberikan simultan tersebut, menginspirasikan implementasi budaya akademik di SD N Bekonang 1, Sukoharjo dalam upaya menciptakan keterampilan sosial siswa yang lebih baik. Oleh sebab itu, dalam rangka melihat lebih jauh keterampilan sosial di SD N Bekonang 1, Sukoharjo maka penelitian ini mengambil tema tentang implementasi budaya akademik bagi keterampilan sosial siswa Sekolah Dasar.

\section{Metode Penelitian}

Penelitian ini menggunakan pendekatan deskriptif-kualitatif. Pendekatan kualitatif digunakan dalam penelitian ini untuk mendeskripsikan implementasi pembelajaran tematik di Sekolah Dasar Negeri Bekonang 1, Sukoharjo. Selain itu pendekatan kualitatif deskriptif lebih efektif digunakan dalam penelitian ini karena dapat menggali data penelitian secara mendalam. Informan dipilih dengan menggunakan purposive sampling. Sedangkan informan dalam penelitian ini adalah guru sejumlah 1 orang yaitu guru kelas $\mathrm{V}$ dan siswa kelas $\mathrm{V}$ sejumlah 31 siswa.

Teknik pengumpulan data yang digunakan peneliti adalah observasi dan dokumentasi. Observasi merupakan kegiatan observasi untuk mendapatkan kedalaman data melalui fenomena yang muncul selama penelitian khususnya mengenai implementasi budaya akademik bagi keterampilan sosial siswa di Sekolah Dasar Negeri Bekonang 1, Sukoharjo. Dokumentasi adalah pencarian data melalui arsip, dokumen, foto yang berkaitan pelaksanaan budaya akademik di SD N Bekonang 1, Sukoharjo.

Selanjutnya dari keseluruhan data yang dikumpulkan melalui observasi dan dokumentasi kemudian diolah dengan menggunakan analisis data interaktif. Adapun analisis interaktif meliputi tahapan reduksi data, penyajian data, dan penarikan kesimpulan.

Gambar 2. Analisis Interaktif Milles \& Huberman

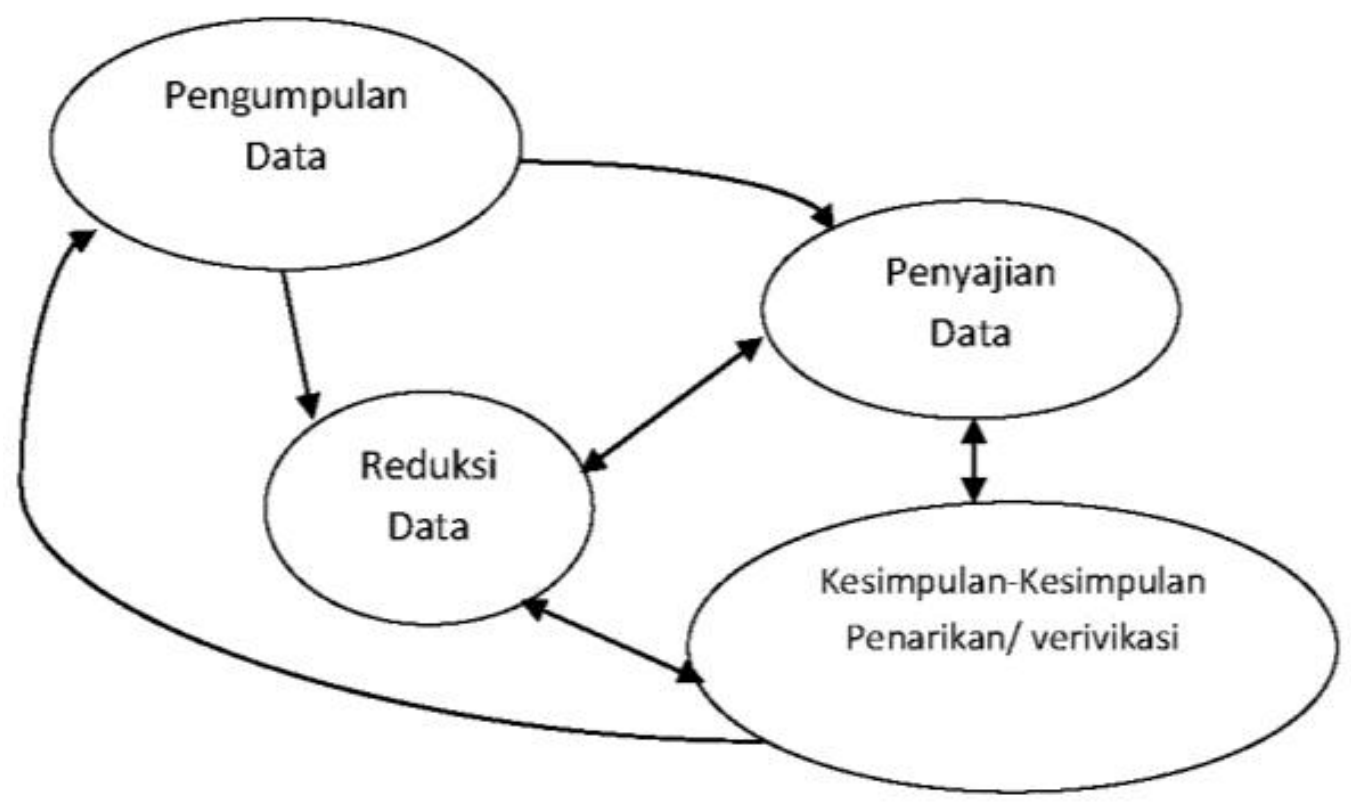




\section{Hasil Penelitian}

Pelaksanaan budaya akademik di SD N Bekonang 1, Sukoharjo khususnya dilakukan pada saat mengajar di kelas. Adapun strategi mengajar yang dilakukan dalam bentuk menghargai prestasi teman, peduli teman ketika membutuhkan bantuan, serta memberi dan meminta maaf. Bentuk budaya akademik tersebut diciptakan oleh guru dalam rangka membangun keterampilan sosial siswa yang lebih baik. Bentuk budaya akademik melalui menghargai prestasi teman terlihat ketika siswa yang tampil didepan kelas, guru memberikan penguatan/reinforcement seperti tepuk tangan dan mengacungkan jempol. Disamping itu, antar siswa juga tidak saling ada kecemburuan dalam tampil di depan kelas. Pembelajaran yang berlangsung tersebut, keterampilan sosial siswa menjadikan siswa lebih terampil dalam memposisikan diri dan temannya tentang hasil karya belajarnya. Budaya akademik selanjutnya adalah peduli teman ketika membutuhkan bantuan. Pembentukan budaya akademik pada siswa dalam hal meminjamkan pensil saat teman lupa tidak membawa pensil. Selain itu, dapat pula terjadi ketika siswa saling menanyakan kabar teman yang tidak masuk. Hal ini keterampilan sosial terbentuk pada siswa untuk memiliki kepekaan dengan lingkungan sekitar secara sosial terampil tanpa harus diperintah oleh guru. Selanjutnya budaya akademik yaitu dalam bentuk memberi dan meminta maaf pada teman. Permasalahan yang muncul di kelas dikarenakan siswa yang heterogen, baik latarbelakang siswa dari kondisi orangtua secara sosial, ekonomi, dan pendidikan pun akan berpengaruh pada sikap toleransi antar sesama ketika berbuat kesalahan. Demikian pula, siswa dengan karakteristik dan kepribadian yang berbeda, perlu memahami apa yang menjadi kemauan dan ketidakmauan siswa. Budaya akademik saling memaafkan dan meminta maaf hal ini tercermin dari kebiasaan. Hal inilah diharapkan dapat membudaya secara keterampilan sosial siswa, tanpa diperintah guru untuk meminta maaf ketika salah ataupun memberi maaf pada teman yang telah berbuat kesalahan. Hal inilah yang berawal terbentuk pada budaya akademik di kelas di SD N Bekonang 1, Sukoharjo sehingga keterampilan sosial siswa terbentuk melalui kebiasaan dari budaya akademik tersebut.

Selain itu, keterampilan sosial pada anak juga dapat disebabkan oleh proses sosialisasi/proses belajar dengan orang tua sejak anak lahir. Orangtua memberikan proses sosialisasi bertujuan agar anak memiliki perilaku, sikap, keterampilan, dan motif-motif sebagai bekal untuk yang sedapat mungkin sesuai dengan yang diinginkan atau tepat dengan perannya di masyarakat. Mengembangkan keterampilan sosial dilakukan melalui menjalin hubungan dengan teman sebaya sebagai media bagi anak untuk mencoba belajar berinteraksi. Selain itu, juga penting adanya pengawasan orang tua dalam proses belajar anak dalam menginternalisasikan nilai-nilai yang disosialisasikan. Sementara itu, jika di lingkungan pendidikan formal, anak-anak harus berinteraksi dan bernegosiasi dengan temantemannya yang memiliki kompetensi sosial, minat, kemampuan, dan gaya interaksi yang berbedabeda. Tidak sedikit anak-anak meminta guru mereka untuk membantunya menghadapi berbagai tantangan yang baru ini. Jika anak-anak tidak diajari untuk berinteraksi dengan baik, bisa dipastikan suasana kelas tidak akan kondusif dan akibatnya akan mengganggu konsentrasi belajar mereka. 
ZAHRA: Research And Tought Elmentary School Of Islam Journal Vol. (2) (1), (Maret)(2021), (Halaman)(1-12)| 7 Kemampuan berinteraksi secara positif sebagaimana ketrampilan dan pengetahuan akademik lainnya, turut berpengaruh terhadap keberhasilan mereka dalam menjalani kehidupan yang sebenarnya.

\section{Diskusi}

Hal ini sependapat dengan Cartledge \& Milburn mengatakan bahwa keterampilan sosial juga berhubungan dengan kemampuan untuk berinteraksi dengan orang lain pada konteks sosial dengan tujuan yang khusus untuk penerimaan sosial. Keterampilan sosial adalah kemampuan yang kompleks guna mendapatkan positif atau negatif reinforcement dan tidak menampilkan perilaku yang menyebabkan hukuman dari orang lain (Cartledge \& Milburn, 1978: 136).

Keterampilan ini juga dapat dilihat sebagai hasil konsekuensi positif bagi individu, tapi dapat diterima dalam norma sosial dan respon terhadap orang lain . Keterampilan sosial juga digunakan sebagai cara yang sangat kompleks untuk hubungan interpersonal. Keterampilan sosial merupakan bagian dari kompetensi sosial. Cartledge \& Milburn menyebutkan bahwa kompetensi sosial terdiri dari tiga konstruk, yaitu penyesuaian sosial, performansi sosial, dan keterampilan sosial. Sementara, kompetensi sosial merupakan suatu hubungan antara orang satu dengan lainnya, baik teman maupun orang yang tidak dikenal. Penyesuaian sosial sebagai salahsatu faktor keberhasilan seseorang dalam beradaptasi pada orang lain secara individu dan kelompok. Performansi sosial adalah wujud tingkah laku seseorang dalam menjalin interaksi dengan orang lain, yang membuahkan suatu hasil dengan baik, seperti kesediaan untuk membantu orang lain, meskipun mereka sendiri mengalami kesulitan dan tidak terikat pada diri sendiri. Bagi seorang anak keterampilan dan kompetensi sosial merupakan faktor yang penting untuk memulai dan memiliki hubungan sosial yang positif. Anak yang tidak memiliki keterampilan sosial akan mengalami kesulitan menjalin hubungan sosial yang positif dengan lingkungannya, bahkan akan ditolak dan diabaikan dengan lingkungannya (Cartledge \& Milburn, 1978: 138-139).

Keterampilan sosial saling memaafkan dan memberi maaf tersebut menjadi dari ruang lingkup keterampilan sosial. Bahwasanya keterampilan sosial dapat dikelompokkan menjadi 4 jenis keterampilan yaitu keterampilan bertahan hidup, interpersonal, pemecahan masalah dan resolusi konflik. Keterampilan bertahan hidup dapat didefinisikan sebagai keterampilan yang mencakup mematuhi aturan dan mengikuti arahan. Selain itu, perintah mendengarkan dan saran juga termasuk dalam keterampilan ini. Keterampilan interpersonal di sisi lain termasuk keterampilan seperti empati, belajar secara kolaboratif, berbagi dan hubungan. Keterampilan pemecahan masalah, secara berbeda, mencakup keterampilan seperti pengambilan tanggung jawab, permintaan bantuan, pengambilan keputusan dan pencarian kemandirian. Akhirnya, keterampilan penyelesaian konflik mencakup keterampilan seperti mengatasi kesulitan dan meminta maaf. Keterampilan ini juga termasuk kedamaian internal dari orang-orang di mana konflik paling banyak terjadi (Gokel, 2017: 7370-7371).

Adanya budaya akademik di SD N Bekonang 1, Sukoharjo tersebut, juga telah diwacanakan di SD Laboratorium Universitas Negeri Malang. Penerapan budaya akademik bertujuan untuk peningkatan kemampuan dan kualitas keterampilan sosial siswa. Bentuk budaya akademik yang 
ZAHRA: Research And Tought Elmentary School Of Islam Journal Vol. (2) (1), (Maret)(2021), (Halaman)(1-12)| 8 diterapkan berupa budaya silent reading atau disebut juga DEAR (Drop Everything And Read), dan budaya menghargai prestasi. Selain itu, juga terdapat budaya demokratis yang diterapkan di SD Laboratorium UM bertujuan agar peserta didik dapat menerapkan sikap toleransi, semangat kebangsaan dan sikap cinta tanah air. Bentuk budaya demokratis yang diterapkan diantaranya budaya menyanyikan lagu Indonesia Raya setiap pagi, menyanyikan lagu daerah dan nasional. Serta dibentuk budaya sosial yang bertujuan agar peserta didik dapat memiliki sikap cinta damai, peduli sosial dan lingkungan dan religious. Bentuk budaya sosial yang diterapkan diantaranya yaitu budaya berdoa sebelum makan, budaya untuk menghargai orang lain, budaya untuk saling bertegur sapa, budaya disiplin, budaya sholat dhuha dan sholat dhuhur di sekolah, budaya amal setiap hari jumat dan budaya berbagi pada sesama (Mustiningsih, 2020).

Selain itu dalam penelitian Laurence menjabarkan contoh keterampilan sosial meliputi (Laurence, 1991: 87-91) :

1. Membuang sampah pada tempatnya.

2. Makan tepat waktu.

3. Berpakaian rapi.

4. Masuk dan keluar kelas dengan sopan.

5. Menolak permintaan orang lain dengan cara yang sopan atau mengucapkan terima kasih.

6. Menerima kritik dan saran orang lain.

7. Menggunakan kata-kata sopan, seperti mengucapkan tolong kepada orang lain.

8. Meminta bantuan dari orang lain.

9. Mengucapkan halo dan memperkenalkan diri kepada orang dewasa dan teman sebaya.

10.Menerima kegagalan dalam pertandingan kompetitif dan mengucapkan selamat kepada pemenang.

11.Permintaan maaf dalam situasi penting.

12.Bekerja sama dengan teman dalam mengerjakan tugas.

13.Sementara menurut Suswandari bahwa beberapa indikator ataupun ciri keterampilan sosial dikembangkan dalam table bawah ini (Suswandari, 2017, 2018).

Tabel 1. Indikator Keterampilan Sosial

\begin{tabular}{|c|c|c|}
\hline \multirow[t]{3}{*}{ No } & $\begin{array}{l}\text { Aspek Keterampilan } \\
\text { Sosial }\end{array}$ & Indikator Keterampilan Sosial \\
\hline & \multirow[t]{2}{*}{ Perilaku Interpersonal } & Cepat tanggap ketika ada teman yang sakit. \\
\hline & & Membantu teman ketika tidak membawa alat tulis. \\
\hline & \multirow{2}{*}{$\begin{array}{l}\text { Perilaku yang } \\
\text { berhubungan dengan Diri } \\
\text { Sendiri }\end{array}$} & $\begin{array}{l}\text { Melakukan kerjasama secara berkelompok ketika } \\
\text { diskusi di kelas. }\end{array}$ \\
\hline & & $\begin{array}{l}\text { Memberi dan meminta memaaf ketika berbuat salah } \\
\text { pada teman. }\end{array}$ \\
\hline & Kesuksesan Akademik & Menyelesaikan tugas dari guru. \\
\hline
\end{tabular}


ZAHRA: Research And Tought Elmentary School Of Islam Journal Vol. (2) (1), (Maret)(2021), (Halaman)(1-12)| 9

\begin{tabular}{|c|c|}
\hline & $\begin{array}{l}\text { Mengerjakan ulangan harian sesuai kemampuan } \\
\text { sendiri. }\end{array}$ \\
\hline & Masuk tepat waktu di kelas. \\
\hline \multirow[t]{3}{*}{ Peer Acepptance } & $\begin{array}{l}\text { Berani mengemukakan pendapat sendiri di depan } \\
\text { teman-teman sekelas. }\end{array}$ \\
\hline & $\begin{array}{l}\text { Menghargai pendapat teman yang memberi saran } \\
\text { dan kritik. }\end{array}$ \\
\hline & $\begin{array}{l}\text { Menghargai pendapat teman ketika diskusi kelompok } \\
\text { di kelas. }\end{array}$ \\
\hline \multirow[t]{2}{*}{ Perilaku Komunikasi } & $\begin{array}{l}\text { Tampil di depan kelas untuk mempresentasikan } \\
\text { diskusi kelompoknya. }\end{array}$ \\
\hline & $\begin{array}{l}\text { Bertanggungjawab atas tugas yang diberikan oleh } \\
\text { guru. }\end{array}$ \\
\hline
\end{tabular}

Berkaitan dengan implementasi budaya akademik di SD N Bekonang 1, Sukoharjo, kajian penelitian di SD Lab.Universitas Negeri Malang dan Laurence tersebut mengindikasikan bahwa penanamana budaya akademik pada pembelajaran siswa di kelas dapat berdampak pada pembentukan kebiasaan siswa secara sosial untuk terampil dalam menghadapi dan peka di lingkungan sekitarnya (Suswandari, 2018 \& 2019).

Seperti yang diungkapkan Fatimah bahwa keterampilan sebagai domain psikomotorik yang bersifat sosial. Artinya bahwa siswa memiliki kemampuan dalam berinteraksi, berkomunikasi dan berpartisipasi dalam kelompok (Haryadi, 2015). Keterampilan sosial sebagai keterampilan berkomunikasi dengan empati dan keterampilan bekerja sama. Hal ini dimaknai bahwa melalui penyampaian pesan/komunikasi tidak hanya pesan dikirimkan tapi juga terdapat kesan yang dimunculkan dalam keberlanjutan komunikasi tersebut secara harmonis dan kesinambungan (Bramantyo \& Prasetyo, 2017; Novianti, 2017).

Berkesinambungan dalam pembentukan keterampilan social juga tidak terlepas oleh beberapa factor. Faktor keterampilan sosial anak ini dilatarbelakangi oleh beberapa faktor seperti kondisi anak sendiri serta pengalaman interaksinya dengan lingkungan sebagai sarana dan media pembelajaran. Keterampilan sosial dilatarbelakangi oleh beberapa faktor berikut ini:

\section{Kondisi Anak}

Penelitian memperlihatkan bahwa anak-anak yang memiliki temperamen akan sulit dan cepat mengalami ketersinggungan secara emosional. Kondisi ini menyebabkan kesempatan mereka untuk berinteraksi dengan teman sebaya berkurang, padahal interaksi merupakan media yang penting dalam proses belajar keterampilan sosial. Sebaliknya, jika anak-anak memiliki keterbukaan akan dapat beradaptasi dengan lingkungan sosial.

Perkembangan keterampilan sosial juga disebabkan oleh kemampuan sosial kognitif yaitu kemampuan memproses semua informasi yang ada dalam proses sosial. Kemampuan ini 
ZAHRA: Research And Tought Elmentary School Of Islam Journal Vol. (2) (1), (Maret)(2021), (Halaman)(1-12)| 10 antara lain adalah kemampuan mengenali isyarat sosial, menginterpretasi isyarat sosial dengan cara yang tepat dan bermakna. Semakin baik keterampilan memproses informasi sosial anak, maka akan semakin mudah baginya untuk membangaun hubungan sportif dengan orang lain dan memiliki keterampilan sosial yang baik.

2. Interaksi Anak Dengan Lingkungannya

Orang tua menginginkan anaknya merasa bahagia dan berhasil pada masa kehidupan anak-anak dan untuk kehidupan selanjutnya. Untuk menjamin bahwa anak mereka akan dapat melakukan penyesuaian sosial yang baik, mereka memberikan kesempatan kepada anak-anak mereka untuk menjalin kontak atau berinteraksi dengan anak-anak lain, dan berusaha memotivasi mereka agar aktif sosial, dengan harapan bahwa tindakan ini akan menimbulkan penyesuaian sosial yang baik. Bukan hanya dengan anak-anak lain, tetapi juga dengan orang tua itu sendiri dan juga lingkungan sekitarnya.

Orangtua juga dapat disebut melalukan pemodelan dalam menanamkan keterampilan sosial pada anak. Interaksi antara orangtua dan anak menentukan kualitas suatu hubungan. Kualitas hubungan tersebut seperti hubungan pertemanan dan penerimaan anak dalam kelompok (Bukowski, Rubin, Bukowski, Parker, \& Bowker, 2008). Proses belajar anak dalam mengembangkan keterampilan sosial dilakukan dalam bentuk peniruan atau modeling terhadap perilaku orang lain, seperti orang tua dan teman sebaya. Hal ini seperti yang dilakukan oleh Megawardani \& Suarni yang ditujukan pada kelompok B di TK Saiwa Dharma Banyuning Singaraja melalui penelitian tindakan kelas. Hasil penelitian menunjukkan bahwa adanya peningkatan keterampilan sosial dikarenakan melakukan aktivitas pembelajaran dengan cara meniru apa yang ada dilingkungannya, seperti perilaku model dalam video. Berdasarkan pengamatan anak kelompok B3 menunjukkan perubahan perilaku setelan mengamati perilaku model. Sebelumnya anak tidak mampu sabar menunggu giliran, berbagi, bekerjasama dan bermain bersama teman setelah melihat, mengamati perilaku model anak mau sabar menunggu giliran, berbagi, kerjasama, dan bermain bersama teman-temannya. Perubahan perilaku yang ditampilkan oleh anak merukan hasil peniruan terhadap perilaku model yang diamati (Megawardani, 2016).

Ananda dan Fadhilaturrahmi serta Hadi juga memberikan pengertian keterampilan sosial (sosial skills) yaitu perilaku spesifik sebagai bentuk perilaku seseorang. Berdasarkan beberapa definisi tersebut dapat diartikan bahwa keterampilan sosial adalah keterampilan yang dimiliki oleh seseorang yang meliputi interaksi, komunikasi, mengemukakan pendapat, percaya diri, disiplin mampu bekerja sama serta bertanggung jawab serta menumbuhkan keharmonisan yang akhirnya berguna sebagai bekal untuk kehidupan sosial. Jika keterampilan sosial ini tidak dimiliki oleh seseorang maka kepercayaan diri akan kurang, ketidakmampuan bekerjasama, kurang bertanggungjawab dan tidak adanya keharmonisan di kelas (Harmiyanto, 2016). 
ZAHRA: Research And Tought Elmentary School Of Islam Journal Vol. (2) (1), (Maret)(2021), (Halaman)(1-12)| 11

Demikian pula, penelitian yang dilakukan oleh Sriyanto bahwa selanjutnya juga dilakukan di sekolah dasar Kecamatan Baturaden, Kabupaten Banyumas berdasarkan hasil observasi di kelas bahwa munculnya keterampilan sosial merupakan bagian dari kemampuan bekerjasama di dalam kelompok besar maupun kecil, menyumbangkan dan menerima pendapat di dalam tugas dan diskusi, serta melalui wujud pengembangan kepemimpinan (Sriyanto, Febrianta, \& Yuwono, 2019: 75).

\section{Simpulan}

Hasil penelitian disimpulkan bahwa implementasi budaya akademik bagi keterampilan sosial siswa di SD N Bekonang 1, Sukoharjo adalah melalui pembelajaran siswa di kelas. Pembelajaran akan berdampak pada pembentukan kebiasaan siswa secara sosial untuk terampil dalam menghadapi dan peka di lingkungan sekitarnya. Bentuk budaya akademik melalui aspek kerjasama antar siswa dalam berkelompok, menolong siswa lain, menyampaikan dan mendengarkan pendapat, peduli teman, saling membantu, serta persaingan akademis. Pembelajaran yang berlangsung tersebut, keterampilan sosial siswa menjadikan siswa lebih terampil dalam memposisikan diri dan keberadaan orang lain dan orang sekitar siswa. Hal inilah yang menjadikan budaya akademik secara imolementasi dapat menumbuhkan keterampilan sosial siswa.

\section{Daftar Pustaka}

Arif, M. (2019). Hubungan Budaya Akademik dan Budaya Organisasi dengan Kinerja Guru. Tadbir : Jurnal Studi Manajemen Pendidikan, 3(1), 17. https://doi.org/10.29240/jsmp.v3i1.804

Bramantyo, R., \& Prasetyo, A. T. (2017). Penerapan Komunikasi Interpersonal Guru Pendidikan Agama Islam di SMP Al-Ulum Terpadu Medan. Ijtimaiyah, 2010(1), 1-89.

Cartledge, G., \& Milburn, J. F. (1978). The Case for Teaching Social Skills in the Classroom: A Review. Review of Educational Research, 48(1), 133-156. https://doi.org/10.3102/00346543048001133

Hammond, L.D., Flook, L., Harvey, C.C, Barron, B \& Osher, D. (2019). Implications for educational practice of the science of learning and development. Applied Developmental Science, O(0), 1-44. https://doi.org/10.1080/10888691.2018.1537791

Harmiyanto, P. \&. (2016). Hubungan Keterampilan Komunikasi Interpersonal Dan Kepercayaan Diri Siswa Kelas X Sman 1 Garum Kabupaten Blitar. Jurnal Kajian Bimbingan Dan Konseling, 1(2), 55-59. https://doi.org/10.17977/um001v1i22016p055

Haryadi, T. \& A. (2015). Melatih kecerdasan kognitif, afektif, dan psikomotorik anak sekolah dasar mellaui perancangan game simulasi "warungku." Jurnal Desain Komunikasi Visual Dan Multimedia, 1(2), 39-50.

Horstman, H. K. (2018). Communication: Oxford Research Encyclopedias (Issue January). Oxford University Press. https://doi.org/10.1093/acrefore/9780190228613.013.278

Janah, M. (2018). Peningkatan Keterampilan Sosial Peserta Didik SMA Menggunakan Layanan Bimbingan Kelompok Dengan Teknik Diskusi Laila Maharani, Hardiyansyah Masya,. Jurnal Bimbingan Dan Konseling, 05(1), 65-72.

Laurence, R. (1991). Division on Mental Retardation-The Council for Exceptional Children. Des Moines Independent Community School District.

Marzius Insani, Pargito, R. M. S. (2005). peningkatan keterampilan sosial dan hasil belajar siswa 
ZAHRA: Research And Tought Elmentary School Of Islam Journal Vol. (2) (1), (Maret)(2021), (Halaman)(1-12)| 12 dengan menggunakan metode bermain peran. In Tesis Pascasarjana Pendidikan IPS FKIP Universitas Lampung (Issue 1, pp. 1-210). Pascasarjana FKIP Universitas Lampung.

Megawardani, S. \& T. (2016). Meningkatkan keterampilan sosial melalui penerapan teknik modeling pada anak Kelompok B TK Saiwa Dharma. E-Journal Pendidikan Anak Usia Dini Universitas Pendidikan Ganesha, 4(3), 2-11.

Mustiningsih, D. (2020). Implementasi Sustained Silent Reading untuk menumbuhkan gemar baca pebelajar SD dengan pendekatan blended learning. Seminar Nasional Arah Manajemen Pada Masa Dan Pasca Covid-19, 46, 354-356.

Novianti, D. (2017). Komunikasi Anatarpribadi Dalam Menciptakan Harmonisasi (Suami Dan Istri) Keluarga Didesa Sagea Kabupaten Halmahera Tengah. E-Journal"Acta Diurna", VI(2), 115. https://media.neliti.com/media/publications/94222-ID-komunikasi-antarpribadi-dalammenciptaka.pdf

Omer Gokel, G. D. (2017). Effects of Social Skill Training Program on Social Skills of Young People. EURASIA Journal of Mathematics, Science and Technology Education, 13(11), 7365-7373. https://doi.org/10.12973/ejmste/79615

Patonah, R. (2016). Pengaruh budaya akademik sekolah terhadapa motivasi belajar siswa dan implikasinya terhadap hasil belajar siswa (survey pada siswa Madrasah Ibtidaiyah Swasta di Kota Banjar). Jurnal Ilmiah Edukasi, 4(3), 281-288.

Santana, S. \& S. (2009). Budaya Akademik Internasional Mahasiswa Indonesia di Australia dan Kanada. Mimbar, XXV(2), 119-142.

Sriyanto, S., Febrianta, Y., \& Yuwono, P. H. (2019). Strategi Berpikir Visual bagi Peserta Didik Gangguan Kecemasan Sosial untuk Mengembangkan Keterampilan Sosial. Jurnal Sains, Sosial, Dan Humaniora, 3, 65-78.

Suswandari, M. (2017). Keterampilan Guru Sekolah Dasar dalam Mengembangkan Bahan Ajar IPS. Edudikara: Jurnal Pendidikan dan Pembelajaran, 2(4), 354-363.

Suswandari, M. (2018). Selayang Pandang Implikasi Aliran Pendidikan Klasik. Jurnal Komunikasi Pendidikan, 1(1), 33-44.

Suswandari, M. (2018). Membangun budaya literasi bagi suplemen pendidikan di Indonesia. Jurnal Dikdas Bantara, 1(1).

Suswandari, M. (2019). Cooperative Learning: Strategi Pengembangan Inovasi Pendidikan Di Indonesia. SCAFFOLDING: Jurnal Pendidikan Islam dan Multikulturalisme, 1(01), 16-24. 